African Crop Science Journal by African Crop Science Society is licensed under a Creative Commons Attribution 3.0 Uganda License. Based on a work at www.ajol.info/ and www.bioline.org.br/cs DOI: http://dx.doi.org/10.4314/acsj.v25i4.9

\title{
POTENTIAL FOR QUALITY PROTEIN MAIZE FOR REDUCING PROTEIN- ENERGY UNDERNUTRITION IN MAIZE DEPENDENT SUB-SAHARAN AFRICAN COUNTRIES: A REVIEW
}

\author{
C.S. NYAKURWA, E. GASURA and S. MABASA \\ Department of Crop Science, Faculty of Agriculture, University of Zimbabwe, P. O. Box MP 167, Mount \\ Pleasant, Harare, Zimbabwe \\ Corresponding author: gasurae@yahoo.com
}

(Received 2 February, 2017; accepted 3 June, 2017)

\begin{abstract}
Most cereal crops, including maize (Zea mays L.), are deficient in essential amino acids, such as lysine and tryptophan; hence they are poor in protein quality. A mutant maize with elevated levels of lysine and tryptophan was developed by the International Maize and Wheat Improvement Centre (CIMMYT) and was called quality protein maize (QPM). Nonetheless, people in sub-Saharan Africa (SSA) continue to use normal endosperm maize (non-QPM) instead of QPM. The objective of this article was to examine the existing information on institutional arrangements, infrastructure and social systems hampering adoption of QPM and to identify opportunities for promoting the campaign for its utilisation in SSA, through innovative research for development initiatives. It is clear that QPM has superior nutritional value, both to humans and to monogastric animals compared to non-QPM. Lack of sound policies and awareness among farmers about the existence and advantages of QPM are some of major drawbacks to QPM adoption and realisation of its benefits. Most farmers hardly believe information regarding nutritional composition of varieties, without convincing visual evidence such as grain yield from demonstration plots. Many African governments have mounted campaigns geared to promote adoption of QPM varieties. Varying levels of QPM adoption have been recorded in South Africa, Burkina Faso, Uganda and Ghana with high QPM production under areas ranging from 12500 to 71250 ha. In order to reduce protein-energy undernutrition (PEU), SSA countries should implement policies that promote QPM adoption such as providing farmers with a premium price for the QPM grain. Results from meta-analysis community based studies revealed that QPM based diets resulted in a 12\% improvement on weight and $9 \%$ increase in height in infant and young children compared to non-QPM based diets. Therefore, quality protein maize bears great potential for reducing PEU and its adoption could be high given that most SSA countries depend on maize as the major source of calories and protein.
\end{abstract}

Key Words: Bio-fortification, lysine, malnutrition, tryptophan, Zea mays L.

\section{RÉSUMÉ}

La plupart des cultures céréalières, y compris le maïs (Zea mays L.), sont déficients en acides aminés essentiels, tels que la lysine et le tryptophane, donc elles sont pauvres en protéines de qualité. Un maïs mutant avec des niveaux élevés de lysine et tryptophane était développé par le Centre International d'Amélioration du Maïs et du Blé (CIMMYT) appelé maïs à protéine de qualité (QPM). Néanmoins, les peuples de l'Afrique Sub-Saharienne (SSA) continuent d'utiliser le maïs à endosperme normal (non-QPM) à la place du QPM. L'objectif de cet article était d'examiner l'information existant sur les dispositions institutionnelles, les infrastructures et les systèmes sociaux empêchant l'adoption du QPM et pour identifier les opportunités pour une campagne de promotion 
pour son utilisation dans les SSA, à travers la recherche innovante pour les initiatives de développement. C'est clair que QPM a une valeur nutritionnelle supérieure au non-QPM, à la fois pour les hommes et les animaux monogastriques. L'absence d'une politique solide et de sensibilisation entre les producteurs concernant l'existence et les avantages du QPM sont les quelques facteurs limitant l'adoption de l'QPM et la réalisation de ses bénéfices. La plupart des producteurs croient difficilement les informations relatives à la composition nutritionnelle des variétés, sans l'existence d'une évidence visuelle comme le rendement en grain des parcelles de démonstration. Plusieurs gouvernements africains ont monté des campagnes pour promouvoir l'adoption des variétés QPM. Des niveaux d'adoption de l'QPM ont été enregistrés en Afrique du Sud, au Burkina Faso, en Ouganda et au Ghana avec une forte production de QPM sur des superficies variant de 12500 à 71250 ha. Dans le but de réduire le dénutrition protéino-énergétique (PEU), les pays du SSA devraient mettre en application les politiques qui favorisent l'adoption des QPM telles que fournir aux producteurs des prix réduits sur les graines de QPM. Les résultats des méta-analyses sur la base des étudies communautaires ont montré que les régimes alimentaires basés sur le QPM résultent en une augmentation de $12 \%$ du poids et $9 \%$ en taille des enfants et des petits enfants comparés aux régimes alimentaires basés sur les non-QPM. Donc, les maïs à protéine de qualité ont un grand potentiel de réduire le PEU et son adoption pourrait être forte étant donné que beaucoup de pays du SSA dépendent du maïs comme source principale d'énergie et de protéine.

Mots Clés: Bio-fortification, lysine, malnutrition, tryptophan, Zea mays L.

\section{INTRODUCTION}

Proper nutrition is important for the social, physical and mental well-being of humans throughout the world. However, proper nutrition remains a challenge, especially in most sub-Saharan African (SSA) countries, whose communities are largely cereal dependent. This has led to two main types of malnutrition; namely protein-energy undernutrition (PEU) (formerly known as protein-energy malnutrition, PEM); and micronutrient deficiency (Bouis and Welch, 2010; Morley, 2016). Pregnant women, the elderly and children under the age of five are the most vulnerable groups to PEU (Müller and Krawinkel, 2005; Mpofu et al., 2014). Hoseini et al. (2015) reported that about 146 million children under the age of five lack adequate protein. Bain et al. (2013) asserted that one third of all children's deaths in SSA was due to PEU manifestation.

The diets of most resource limited people are mainly composed of cereals, with inadequate protein sources such as meat and eggs (Gupta et al., 2009; Maseta et al., 2017). To avoid PEU, all essential amino acids must be present in the human diet. The normal endosperm maize commonly found in diets naturally has all essential amino acids, except lysine and tryptophan thus making it impossible to combat PEU without supplementation with other rich protein sources (Bharti et al., 2017). Despite the maize endosperm having other essential amino acids, lysine and tryptophan are equally essential in protein synthesis for tissue growth and also the conversion of tryptophan to niacin in the body reduces the incidence of pellagra (Babu and Prasanna, 2014; Motuma et al., 2015; Sharma et al., 2017).

The International Maize and Wheat Improvement Centre (CIMMYT) discovered a mutant maize with an opaque-2 gene, which codes for a double increase in levels of the two most limiting essential amino acids for growth and development of humans and animals; lysine and tryptophan (Luong et al., 2017). This mutant maize had other pleiotropic negative agronomic traits, which were eventually overcome through CIMMYT's conventional breeding methods, leading to the development of a variety with desirable agronomic traits that was termed quality protein maize (QPM) (Pandey et al., 2016; Messing and Rutgers, 2017). Several researchers have reported the nutritional benefits of QPM in humans and monogastric animals (Galili and Amir, 2013; Vaswani et al., 2015; Dei et al., 2017). However, communities 
solely dependent on maize in their diets still record high PEU prevalent rates. This is mainly attributable to paucity of information among concerned communities about the existence and the nutritional benefits of QPM, in complementing protein needs of humans (De Groote et al., 2010; Kadafur et al., 2017). Furthermore, many other factors have obscured the promotion of QPM, particularly in SSA, due to lack of awareness campaigns on the benefits of QPM (Gregory and Sewando, 2013; De Groote et al., 2016). It was, therefore, prudent for this 2017 review to examine the existing information on institutional arrangements, infrastructure and social systems hampering QPM promotion and adoption and to identify opportunities for promoting the campaign for adoption and utilization of QPM varieties in SSA, to greater heights, through innovative research for development initiatives.

Protein-energy undernutrition and related challenges. Protein-energy undernutrition is an energy shortfall owing to the deficit of macronutrients such as proteins (Jensen et al., 2009; Morley, 2016). It can be acute (for example starvation) or chronic. Severity ranges from subclinical shortages to noticeable wasting (hair discoloration and loss, edema, and skin peeling), to starvation causing numerous malfunctioning of organ systems (Sivaramakrishnan and Patel, 2017).

Protein-energy undernutrition is usually diagnosed using laboratory testing, including serum albumin (Morley, 2016). Alleviation of PEU includes rectifying fluid and electrolyte anomalies and gradual nutrient replenishing, which can be done orally (Hofer et al., 2014). As a nutrient, protein is critically important to the body as it has many functions, including provision of essential amino acids for growth and tissue repair (Henley et al., 2010). The detrimental effects caused by PEU directly affects growth and development. Proteinenergy undernutrition primarily manifest as kwashiorkor and marasmus (Bain et al., 2013;
Morley, 2016). Kwashiorkor (nutritional edema) involves a fair to normal calories intake, with insufficient protein intake; whereas Marasmus (absence of edema) involves inadequate protein and calorie consumption (Bain et al., 2013). According to van der Pols-Vijlbrief et al. (2014), PEU leads to a plethora of health problems, which may include high mortality rates, increased health care costs, poor intellectual development and disorderly physical functioning in older adults.

Prevalence of PEU in SSA. The sub-Saharan region has the highest prevalence of undernourishment in the word, with more than one person in four people stunted due to lack of nutritious food (UNICEF, 2013; Ghosh $e t$ al., 2012; Maseta et al., 2017). Steyn and Mchiza (2014) reported that African countries such as Zambia, Rwanda and Zimbabwe recorded a low protein intake since 1980, signifying the need to promote initiatives geared to enhancing access and utilisation of readily available protein rich dietary resources in SSA.

Research has shown that one in every two children is wasted or stunted in Ethiopia, Madagascar and Burundi (UNICEF, 2013). It has also been long noted that undernutrition is prevalent among older African males and females with estimated prevalence of 9.5$36.1 \%$ and $13.1-27 \%$, respectively (Charlton and Rose, 2001). Nuss and Tanumihardjo (2011) and Steyn and Mchiza (2014) noted that dietary protein per capita in Malawi, Madagascar, Lesotho, Zambia and Zimbabwe had decreased to less than $50 \mathrm{~g}$ per day, per capita, since 1980 , thereby worsening the problem of PEU in the region. These statistics are alarming, given that protein provides the body with much needed essential amino acids, such as lysine and tryptophan; hence high risk for malnutrition associated diseases due to weakened immune system (Prasanna et al., 2001). Rich protein foods such as meat and eggs are rarely consumed by resource limited 
communities due to prohibitive costs (Nuss and Tanumihardjo, 2011).

Factors such as poverty, inadequate education, lack of sound policies and climate change vulnerability contribute heavily to the prevalence of PEU in SSA (De Onis et al., 1993; Bain et al., 2013; Goudet et al., 2017).

Poverty factor. Poverty is regarded as the major contributory factor to communities' failure to procure food in SSA (Bain et al., 2013; Ubesie and Ibeziakor, 2013). Without the necessary resources to secure food, many households are deprived from good nutrition due to lack of dietary diversity (Mkonda and He, 2017; Owach et al., 2017). For example, Akombi et al. (2017) reported that at least one third of undernourished children in the world reside in Africa, which is mostly comprised of third world countries; thus cementing the fact that poverty leads to PEU. Similarly, it is estimated that one person out of seven suffers PEU in countries like Zambia due to high levels of poverty (Mubanga and Ferguson, 2017; Puskur et al., 2017). However, effective partnerships among governments, the private sector and the civil society geared to alleviating poverty, such as intensifying food production and nutrition security will be necessary to achieve country and regional food security targets. Poverty reduction will see communities being able to afford not only alternative rich sources of protein but also able to purchase QPM seed leading to PEU reduction.

Education level. Education plays a significant role in deciding the nutritional status of communities in a given environment (Alaofè et al., 2017; Akombi et al., 2017). SubSaharan Africa reportedly has the lowest education levels globally (Asiedu, 2014); thus precipitating the PEU predicament. It has been reported that at least $40 \%$ of the world's outof-school children, are found in SSA (Asiedu, 2014).

Uneducated women present high chances of disadvantaging children in terms of good healthy practices, such as exclusive breastfeeding and child access to healthy nutritious food, thereby contributing to increased PEU (Mehrotra, 2006; Akombi et al., 2017). Akombi et al. (2017) concurred that households with parents of low education levels tend to have low disposable income and, hence, are likely to spend less on proper nutrition, resulting in PEU. However, it has been shown that new technology awareness such as QPM, is not related to education level, but its adoption is related to the education level of the target people (Taipale, 2013, Ghimire and Huang, 2015). Therefore, as a counter measure, there is need to tap in the existing education in countries such as Tanzania, Malawi, Kenya and Zambia to use it as a vehicle for QPM campaigns on the benefits of QPM (Langsten, 2014; Orodho, 2014; Zinkina and Korotayev, 2014). Education promotion, which has been widely implemented in SSA region, through government initiatives such as free primary education for all, should be used as the right platforms to spread information on the existence and nutritional qualities of QPM, in order to reduce the burdens of PEU (Atuhurra, 2016). In 2006, Ghana was one of the African countries that implemented a primary child school feeding programme in line with the agenda of the New Partnership for Africa's Development (NEPAD) (Asiedu, 2014). As a credit to the programme, enrolment doubled and many are literate and now the right target for the QPM campaigns leading to the successful adoption of QPM in Ghana (Asiedu, 2014; Awunyo-Vitor et al., 2016). According to Steyn and Mchiza (2014) and Mabhaudhi et al. (2016) education enables the acquirement of skills that would empower households to have better access and understanding to human nutritional education information.

Sound policies. Similarly, the lack of sound policies, such as making it compulsory for each and every seed company to produce at least one QPM seed variety, may also be contributing to the prevalence of PEU in SSA. 
As an example, Kinabo (2014) reported that available policies in Tanzania are more inclined on enhancing food availability rather than nutrition in particular hence not addressing the issue of PEU. According to Frelat et al. (2016) national policies and local interventions have intense bearings on the opportunities and constraints that affect the nation. Kinabo (2014) further reported that approximately $43 \%$ of policy documents from different ministries in Tanzania do not include any explicit mention of nutrition, hence the need to have sound policies which put more emphasis on PEU alleviation.

However, Frelat et al. (2016) interjected that policy frameworks should prioritize the nutrition agenda in all other policies since nutrition is a paramount and cross-cutting issue in order to improve the PEU status in SSA. Moreover, governments in countries such as Zambia, Zimbabwe and Malawi should propose and implement policies such as those advocating for half of the maize produced on the market to be QPM varieties. Also, policies that advocate for compulsory production of at least one QPM seed variety from each present seed company will also help to promote QPM production by making the QPM seed easily available and accessible, thereby aiding in alleviating PEU. Furthermore, there should be recommendations to inject open pollinated QPM varieties into communities, which will be non-formal seed sources. On a positive note, countries such as Rwanda implemented the National Food and Nutrition Policy, which forms the basis for the National Food and Nutrition Strategic Plan of 2013-2018 (NFNSP) in which the Rwandan government with the help of the World Health Organisation (WHO) seeks to fight PEU (WHO, 2014). The NFNSP attempts to prevent the prevalence of PEU by bringing together many interventions that protect women of child bearing age and children under the age of five from malnutrition starting from the first one thousand days (the period from conception through two years of life when stunting in children occurs). The plan also advocates for communication campaigns promoting adoption of nutritious bio-fortified crops such as QPM to meet the protein-energy requirement of the Rwandan citizens (WHO, 2014).

Population growth. Sub-Saharan Africa has been reported to have the highest world population growth rate of $2.5 \%$ per annum (Bongaarts et al., 2013; Naidoo et al., 2014). This increase in population has increased the stress on the limited resources available in most SSA countries in the fight against PEU (Shiferaw et al., 2014). This is mainly because some countries have failed to implement sustainable population regulation policies. For example, in 2009, Mali initiated the Family Code amendment, a policy which raised the legal marriage age to 18 in order to reduce population growth in the fight against PEU (May, 2017). However, this policy was eventually altered after the Muslim society in Mali demonstrated against it. This was clearly a setback due to the problem of policy space (a matrix of outcomes of anticipated scenarios resulting from policy changes), which aggravates the PEU menace (May, 2017). Moreover, countries such as Uganda are reported to have policies opposed to population reduction programmes, which in return strains available resources to combat PEU resulting in the 52\% of the children suffering from PEU (Kakooza Mwesige et al., 2015; May, 2017). This clearly show that some African policy makers prioritise other developmental matters without endorsing the need to reduce population growth, which gives pressure on the available limited resources to reduce PEU (May, 2017).

According to Frelat et al. (2016), multisectoral policy coordination, recognising and understanding diverse households in SSA is key for the designing of policies that aim to improve food and nutrition security. Sunguya et al. (2014) earlier added that resilient nutrition governance aids in bringing down the magnitude of PEU in SSA. Moreover, 
education programs geared towards sustainable family growth can be used as good approaches to regulate family size and population growth thereby contributing to improving nutritional standards, which is a positive step to alleviation of PEU.

Climate change and variability. Climate change is another factor which needs to be considered when discussing about PEU management (Marx et al., 2014; ConnollyBoutin and Smit, 2016; Phalkey et al., 2016). The impact of climate change presents threat to Africa because of its climate sensitive economies (mainly agriculture based), than any other continent; and only through agricultural production can PEU be significantly reduced. Climate change effects are already being felt world over; especially in SSA, due to limited capacity to adapt (Nhemachena et al., 2014). Agricultural production is largely being affected by climate change, which in turn vehemently affect human nutrition in a negative way leading to PEU prevalence (Bain et al., 2013; Chivenge et al., 2015; Connolly-Boutin and Smit, 2016). Sustainable solutions to climate change and variability come in the form of what have become to known as climate smart agriculture (Mbow et al., 2014; Notenbaert et al., 2017). Climate smart agriculture strives to reduce further emissions of greenhouse gases through reduction of usage of in-organic chemicals and promotion of sustainable farming systems such as conservation agriculture, which can boost agricultural productivity leading to PEU reduction (Altieri and Nicholls, 2017, Brandt et al., 2017; Thierfelder et al., 2017). Moreover, there is intensification of breeding maize (QPM) varieties adapted to harsh environmental conditions such as drought by international organisations such as CIMMYT in order to curb PEU in SSA (Setimela et al., 2017).

Protein-energy management strategies. Nutrient supplementation and crop bio- fortification are the major strategies being used to reduce PEU in sub-Saharan Africa (Low et al., 2015; Talsma et al., 2016; De Valença et al., 2017). Nutrient supplementation involves the addition of nutrients to diets in order to help some people meet their nutrient requirements (Marra and Boyar, 2009). For example, country wide vitamin A supplementation to infants, young children and women of bearing age has been implemented in African countries such as Kenya, Uganda, Tanzania, Zambia and Zimbabwe through their respective Ministries of Health (Low et al., 2015; Wirth et al., 2017). Additionally, in South Africa, progress has been made to control micronutrient deficiency through food fortification and supplementation, especially for the rural poor communities (Joint, 2012).

Biological fortification, also commonly known as bio-fortification allows for increased content of certain nutrients of crops and animals to be available for human consumption (Gunaratna et al., 2010). Bio-fortification is relatively a new technology, which is being promoted worldwide to combat hidden hunger (undernutrition), which is as a result of most communities relying on staple foods, which lack some nutrients resulting in increased incidence of malnutrition (Machida et al., 2014). It has been scientifically reported that bio-fortification is feasible without compromising agronomic productivity for crops such as maize; with high protein quality and vitamin A, that is QPM and pro-vitamin A maize, respectively (Andersson et al., 2017; Covic et al., 2017; Potrykus, 2017); hence bio-fortification is the way to go. Bio-fortified crops such as QPM have been developed to fight the problem of PEU in maize dependent communities such as the SSA. In Ghana, QPM production is high and QPM-based diets among children have been reported to promote good health (Abiose et al., 2015).

People in the rural communities in SSA region try to compensate protein shortage with legumes in their diets (Table 1). However, legumes lack sulphur-containing amino acids 
TABLE 1. Comparison of protein quantity and quality (lysine and tryptophan levels) of non- QPM and legume grains which make common diets in sub- Saharan Africa with QPM

\begin{tabular}{llll}
\hline Source & Protein & Lysine & Tryptophan \\
\hline Glycine max $\mathrm{L}$. & $40.1-44.5^{\mathrm{a}^{*}}$ & $6.3^{\mathrm{h} \ddagger}$ & $1.3^{\mathrm{h} \ddagger}$ \\
Arachis hypogea $\mathrm{L}$. & $23.5-26.6^{\mathrm{a}^{*}}$ & $0.93^{\mathrm{d}^{*}}$ & $0.31^{\mathrm{d}^{*}}$ \\
Vigna unguiculata $\mathrm{L}$. & $15.5-15.7^{\mathrm{a}^{*}}$ & $5.7^{\mathrm{g}^{*}}$ & $3.2^{\mathrm{g}^{*}}$ \\
Phaseolus vulgaris $\mathrm{L}$. & $15.1-15.4^{\mathrm{a}^{*}}$ & $7-7.4^{\mathrm{f \#}}$ & $0.31-0.32^{\mathrm{e}^{*}}$ \\
QPM & $10^{\mathrm{c} \dagger}$ & $2.7-4.5^{\mathrm{b} \dagger}$ & $0.5-1.1^{\mathrm{b} \dagger}$ \\
Non-QPM & $10^{\mathrm{c} \dagger}$ & $1.6-2.6^{\mathrm{b} \dagger}$ & $0.2-0.5^{\mathrm{b} \dagger}$ \\
\hline
\end{tabular}

${ }^{\mathrm{a}}$ (Kwiri et al., 2015); ${ }^{\mathrm{b}}$ (Krivanek et al., 2007); ${ }^{\mathrm{c}}$ (Ignjatoviæ-Miciæ et al., 2008; Wahab et al., 2012); ${ }^{\mathrm{d}}$ (Ingale and Shrivastava, 2011); ${ }^{\mathrm{e}}$ (Comai et al., 2007); ${ }^{\mathrm{f}}$ (Baudoin and Maquet, 1999); ${ }^{\mathrm{g}}$ (Otemuyiwa and Adewusi, 2014); h(Hulshof et al., 2017). $*, \dagger, \#$ and $\ddagger$ represents $\mathrm{g} 100^{-1} \mathrm{~g}$; total protein $\%$; $\%$ of total amino acids and $\mathrm{g} \mathrm{kg}^{-1}$ dry matter

such as methionine, which are also essential in protein synthesis, and are not consumed often compared to cereals such as maize and hence a drawback in fighting PEU (Ingale and Shrivastava, 2011; López Barrios et al., 2014; Owuamanam et al., 2014). Suggesting that QPM can be singled out as one of the most suitable and promising gate away to alleviating PEU especially in SSA since maize constitute a greater part of the daily diets in this region.

Quality protein maize an alternative way to combat protein-energy undernutrition. According to Sofi et al. (2009) and Nuss and Tanumihardjo (2010), almost one third of the global population, including SSA countries, rely mostly on cereals, especially rice and maize for their major supply of protein and energy. Available information shows that maize has a global protein contribution of $15 \%$, which is not enough to meet the demands for world protein requirements (Sofi et al., 2009). Hence, bio-fortified cereal crops such as the QPM, which can easily fit into the farming and food systems in SSA, have the potential to reduce the protein and essential amino acid inadequacy gaps in most developing cereal dependent countries (Nuss and Tanumihardjo, 2011).

QPM has an opaque-2 gene, which codes for high levels of the two essential amino acids; lysine and tryptophan, and as a result it is highly superior to normal endosperm maize (nonQPM) in terms of nutrition (Sofi et al., 2009; Singh et al., 2012; Bisen et al., 2017). NonQPM varieties have an average of about $2 \%$ lysine and $0.4 \%$ tryptophan; whereas lysine and tryptophan levels in QPM average about 4 and $0.8 \%$ of the total protein content, respectively (Prasanna et al., 2001; Krivanek et al., 2007; Ignjatoviæ-Miciæ et al., 2008; Kiria et al., 2010). QPM constitutes $80 \%$ of the biological value of cow milk, compared to 45\% of non-QPM (Machida et al., 2014; Rajendran et al., 2014). Mbuya et al. (2010) reported that QPM contains 70 to $100 \%$ more of lysine and tryptophan than non-QPM. These amino acids are used to make complete proteins in the body, and tryptophan reduces the incidence of PEU (pellagra and kwashiorkor) in children (Graham et al., 1990).

It has been reported that QPM varieties have yielded positive benefits in Mexico, Central America and China for yield and reduction of PEU (Mbuya et al., 2010). QPM has been shown to be of nutritive value both as a human food, especially for children and women of reproductive age and as an animal feed particularly the non-ruminants (Bello et al., 2014). In China, QPM hybrids were 
recorded to attain yields which are $10 \%$ higher than those of non-QPM varieties (Mbuya et al., 2010). Information from different studies shows that the crop has the potential to boost pig and poultry production, thereby increasing disposable income, food and nutrition security (Nuss and Tanumihardjo, 2011).

Researches carried out in countries including Ghana and Ethiopia revealed that children with kwashiorkor responded positively to diets with opaque-2 proteins (Krivanek et al., 2007; Nuss and Tanumihardjo, 2011). Studies confirmed that rats fed with $90 \%$ QPM for 28 days gained an average of $97 \mathrm{~g}$, while those fed on non-QPM varieties attained an average of $27 \mathrm{~g}$ (Kiria et al., 2010; Boateng et al., 2012). These findings clearly demonstrate that QPM would be superior to non-QPM varieties, if used in the diet of humans and monogastric animals and can significantly contribute to PEU alleviation (Kiria et al., 2010). Furthermore, researchers have revealed that approximately $100 \mathrm{~g} \mathrm{QPM}$ is adequate for children to maintain the required levels of lysine and about $500 \mathrm{~g}$ is adequate for adults, thereby reducing maize intake required to meet sufficient body protein by $40 \%$ as compared to non-QPM varieties (Nuss and Tanumihardjo, 2011).

Current efforts in the promotion of QPM production. According to Bello et al. (2014) QPM and non-QPM varieties can only be differentiated through laboratory tests because based on phenotypic appearance they look the same. Research has shown that QPM varieties exhibit the same agronomic performance as non-QPM varieties (Bello et al., 2014). Researches which demonstrate the yield and agronomic performance of QPM are important so as to convince farmers to undertake the adoption process of the QPM varieties. This is primarily because most farmers from the SSA region are more interested in the yield and agronomic performance of a variety than the nutritional composition which they cannot measure. Moreover, similarities of QPM to non-
QPM varieties in terms of yield and agronomic performance, phenotypic appearance and palatability represent the strengths of QPM varieties, which needs to be exploited when promoting its adoption. Furthermore, QPM has the greatest opportunity to reduce PEU in SSA, since most communities in this region mostly cultivate and consume maize, hence QPM can easily fit in the food and farming systems of these communities due to its physical similarities to non-QPM.

Twumasi-Afriyie et al. (2016) reported that an estimated area of one million ha of land in SSA was under QPM production in 2015. Initially, QPM promotion began in Ghana and several other African countries, but its research has spread throughout the world. As reported by Krivanek et al., (2007), Sofi et al. (2009) and Machida et al. (2014), 30 million ha is under maize production in the sub-Saharan region, but only less than $1 \%$ is approximated to be under QPM production; yet they share the same agronomic practices (Table 2). The low adoption of QPM varieties in many SSA countries can be attributed to the fact that the technology is still new and as a result a lot of maize farmers do not even know that maize with such benefits exists (Machida et al. (2014). It, therefore, calls for an increase in awareness campaigns involving mostly resource poor communities' in order to improve the adoption of QPM varieties in the fight against PEU.

In Africa, Ghana (Table 2) was the pioneer of QPM development and adoption, with its initial release of the much popular Obatanpa variety in 1992; and subsequent release of the other three varieties in 1997 covering an estimated area of 70000 ha (Boateng et al., 2012; Andam et al., 2017). Countries such as Uganda, Burkina Faso and South Africa (Table 2) produce significant amounts of $Q P M$ (Twumasi-Afriye et al., 2016). In Zimbabwe, several seed companies have availed QPM varieties such as MQ623 known as "Mama" from Mukushi Seeds, SC643 from Seed Co and ZS261Q from ARDA Seeds (Derera, Prof, 
TABLE 2. African countries QPM production arranged according to area under QPM production

\begin{tabular}{lrl}
\hline Country & Area under QPM production (ha) & Production description \\
\hline Ghana & 71250 & High \\
Uganda & 46717 & High \\
Burkina Faso & 20600 & High \\
South Africa & 12500 & High \\
Mozambique & 11250 & High \\
Mali & 9000 & Medium \\
Ethiopia & 7283 & Medium \\
Nigeria & 4500 & Low \\
Benin & 4325 & Low \\
Tanzania & 4300 & Low \\
Guinea & 3875 & Low \\
Malawi & 1125 & Low \\
Togo & 750 & Very low \\
Cote d'Ivoire & 565 & Very low \\
Senegal & 500 & Very low \\
Cameroon & 305 & Very low \\
Kenya & 12 & Very low \\
Zimbabwe & - & New adopters \\
\end{tabular}

Modified from Krivanek et al. (2007)

Seed Co Pvt Ltd, 2016; MacRoberts, Dr, Mukushi Seeds Pvt Ltd, 2016; Mhike, Dr, Pioneer Hi-bred International, 2016). Currently, the University of Zimbabwe in partnership with a non-governmental organisation; Welthungerhilfe under the Sustainable Intensification of Market Based Agriculture project are carrying out a research to promote the adoption of quality protein maize and orange fleshed sweet potato in Gokwe south district in order to curb PEU.

National nutrition policies. In SSA, several governments support the issue of nutrition, for instance Burkina Faso and Mali developed specific policies such as the National Plan of Action for Nutrition and the National Programme Plan for Food Fortification, respectively (Birner et al., 2007). These policies are meant to help the nations to fight against PEU. In Zimbabwe, the government adopted a policy document; "the Zimbabwe Agenda For Sustainable Socio-Economic Transformation (ZIMASSET)" which spells out the need to create a self-sufficient and food surplus economy (Bonga, 2014). The ZIMASSET has clusters which include the one for Food Security and Nutrition. The government is also supporting private sector and donor supported non-governmental organisations, which are working in collaboration with the Ministry of Agriculture, Mechanisation and Irrigation Development for the promotion and production of bio-fortified crops such as QPM to lessen the problem of PEU. Furthermore, under the Command Agriculture policy, inputs are provided and farm management monitored resulting in bumper harvest (The Herald, 26 August 2017), thus increasing availability of quality food such as QPM. These are some of the countries implementing nutrition policies by trying to emulate Ghana. In Ghana, the success of QPM adoption and production is largely attributed to the promotional activities which involved state policy makers, Sasakawa Global 2000 and other private sectors (Machida et al., 2014).

However, as asserted earlier some governments in SSA are not subsidizing QPM 
production and initiating awareness campaigns to drive adoption; and traders are not willing to pay a premium price for QPM grain (Kiria et al., 2010). All these factors have contributed to the slow adoption rates of QPM in SSA. Sub-Saharan African countries need to implement sound policies such as making it compulsory for every seed company in the region to produce at least one QPM seed variety in order to increase seed availability and accessibility to communities in trying to combat PEU.

\section{CONCLUSIONS}

QPM has the potential to combat PEU in many developing countries in SSA, which solely depend on maize for the bulk of their daily diets. QPM has been proven to exhibit the same agronomic performance as non-QPM varieties, hence, does not require any special agronomic practices and can be easily incorporated in smallholder farming and food systems in order to curb PEU. Nonetheless, QPM adoption has been slowed by the fact that the QPM distinctiveness is unnoticeable; hence farmers cannot hastily adopted QPM varieties as based on the purported nutritional value. Rather they would want high yielding varieties, since it is one of the major criteria used to select varieties to grow. Therefore, there is need to do many demonstration plots such that farmers can visually appreciate the similarity of yield and related agronomic performance between QPM and non-QPM varieties. With sound policies, infrastructure and campaigns for QPM, the protein nutrition of children, women of reproductive age and the elderly will improve significantly.

\section{ACKNOWLEDGEMENT}

We would like to extend our gratitude to $\mathrm{Mr}$. J.T. Rugare for valuable comments during the preparation of this manuscript.

\section{REFERENCES}

Abiose, S.H., Ikujenlola, A.V. and Abioderin, F.I. 2015. Nutritional quality assessment of complementary foods produced from fermented and malted quality protein maize fortified with soybean flour. Polish Journal of Food and Nutrition Sciences 65:49-56. Akombi, B.J., Agho, K.E., Hall, J.J., Wali, N., Renzaho, A. and Merom, D. 2017. Stunting, Wasting and Underweight in SubSaharan Africa: A Systematic Review. International Journal of Environmental Research and Public Health 14:863.

Alaofè, H., Burney, J., Naylor, R. and Taren, D. 2017. Prevalence of anaemia, deficiencies of iron and vitamin A and their determinants in rural women and young children: a cross-sectional study in Kalalé district of northern Benin. Public Health Nutrition 20(7):1203-1213.

Altieri, M.A. and Nicholls, C.I. 2017. The adaptation and mitigation potential of traditional agriculture in a changing climate. Climatic Change 140:33-45.

Andam, K.S., Johnson, M.E., Ragasa, C., Kufoalor, D.S. and das Gupta, S. 2017. A chicken and maize situation: The poultry feed sector in Ghana (No. 1601). International Food Policy Research Institute (IFPRI).

Andersson, M.S., Saltzman, A., Virk, P.S. and Pfeiffer, W.H. 2017. Progress update: crop development of biofortified staple food crops under HarvestPlus. African Journal of Food, Agriculture, Nutrition and Development 17(2):11905-11935.

Asiedu, E. 2014. Does foreign aid in education promote economic growth? Evidence from Sub-Saharan Africa. Journal of African Development 16:37-59.

Atuhurra, J.F. 2016. Does community involvement affect teacher effort? Assessing learning impacts of Free Primary Education in Kenya. International Journal of Educational Development 49:234-246. 
Awunyo-Vitor, D., Wongnaa, C.A. and Aidoo, R. 2016. Resource use efficiency among maize farmers in Ghana. Agriculture \& Food Security 5(1):28.

Bain, L., Awah, P., Geraldine, N., Kindong, N., Sigal, Y., Bernard, N. and Tanjeko, A. 2013. Malnutrition in Sub-Saharan Africa: burden, causes and prospects. Pan African Medical Journal 15:120.

Babu, R. and Prasanna, B.M. 2014. Molecular breeding for quality protein maize (QPM). In: Genomics of plant genetic resources. Springer Netherlands. pp. 489-505.

Baudoin, J.P. and Maquet, A. 1999. Improvement of protein and amino acid contents in seeds of food legumes. A case study in Phaseolus. Biotechnologie, Agronomie, Société et Environnement 3(4):220-224.

Bello, O.B., Olawuyi, O.J., Ige, S.A., Mahamood, J., Afolabi, M.S., Azeez, M.A. and Abdulmaliq, S.Y. 2014. Agronutritional variations of quality protein maize (Zea mays L.) in Nigeria. Journal of Agricultural Sciences 59:101-116.

Bharti, B., Dubey, R.B., Kumar, A., Dadheech, A. and Dhobi, R.K. 2017. Stability Analysis for Grain Yield and Quality Parameters in QPM (Zea mays L.) Inbred Line Crosses. International Journal of Current Microbiology and Applied Sciences 6(6):3177-3185.

Birner, R., Kone, S.A., Linacre, N. and Resnick, D. 2007. Biofortified Foods and Crops in West Africa: Mali and Burkina Faso. AgBioForum 10:192-200.

Bisen, P., Dadheech, A., Namrata, O.N. and Meena, R.K. 2017. Exploitation of heterosis in single cross hybrids of quality protein maize (Zea mays L.) for yield and quality traits. International Journal of Bioresource and Stress Management 8(1):012019.

Boateng, M., Okai, D.B., Salifu, A. and Ewool, M.B. 2012. A comparative study of two normal maize and two Quality Protein Maize varieties-Effects on growth performance and carcass characteristics of albino rats. Journal of Animal Science Advances 2:787-792.

Bongaarts, J. and Casterline, J. 2013. Fertility transition: is sub Saharan Africa different? Population and Development review 38(s1):153-168.

Bonga, W.G. 2014. Economic policy analysis in Zimbabwe: A review of Zimbabwe economic policies: Special reference to Zimbabwe agenda for sustainable socioeconomic transformation (Zim Asset). Available at SSRN 2384863. Accessed 10 May 2016.

Bouis, H.E. and Welch, R.M. 2010. Biofortification: A sustainable agricultural strategy for reducing micronutrient malnutrition in the global south. Crop Science 50:S-20-S-32.

Brandt, P., Kvakiæ, M., Butterbach-Bahl, K. and Rufino, M.C. 2017. How to target climate-smart agriculture? Concept and application of the consensus-driven decision support framework "targetCSA". Agricultural Systems 151:234-245.

Charlton, K.E. and Rose, D. 2001. Nutrition among older adults in Africa: The situation at the beginning of the millenium. The Journal of Nutrition 131:2424S-2428S.

Chivenge, P., Mabhaudhi, T., Modi, A.T. and Mafongoya, P. 2015. The potential role of neglected and underutilised crop species as future crops under water scarce conditions in Sub-Saharan Africa. International Journal of Environmental Research and Public Health 12:5685-5711.

Comai, S., Bertazzo, A., Bailoni, L., Zancato, M., Costa, C.V. and Allegri, G. 2007. Protein and non-protein (free and proteinbound) tryptophan in legume seeds. Food Chemistry 103:657-661.

Connolly-Boutin, L. and Smit, B. 2016. Climate change, food security, and livelihoods in sub-Saharan Africa. Regional Environmental Change 16:385-399.

Covic, N., Low, J., MacKenzie, A. and Ball, A. 2017. Advocacy for biofortification: 
building stakeholder support, integration into regional and national policies, and sustaining momentum. African Journal of Food, Agriculture, Nutrition and Development 17(2):12116-12129.

Dei, H.K. 2017. Assessment of Maize (Zea mays) as Feed Resource for Poultry. In Poultry Science. InTech.

De Groote, H., Gunaratna, N., Ergano, K. and Friesen, D. 2010, September. Extension and adoption of biofortified crops: Quality protein maize in East Africa. In Contributed Paper presented at the Joint 3rd African Association of Agricultural Economists (AAAE) and 48th Agricultural Economists Association of South Africa (AEASA) Conference, Cape Town, South Africa.

De Groote, H., Gunaratna, N.S., Fisher, M., Kebebe, E.G., Mmbando, F. and Friesen, D. 2016. The effectiveness of extension strategies for increasing the adoption of biofortified crops: the case of quality protein maize in East Africa. Food Security 8(6):1101-1121.

De Onis, M., Monteiro, C., Akré, J. and Clugston, G. 1993. The worldwide magnitude of protein-energy malnutrition: an overview from the WHO Global Database on Child Growth. Bulletin of the World health Organization 71:703- 712.

De Valença, A.W., Bake, A., Brouwer, I.D. and Giller, K.E. 2017. Agronomic biofortification of crops to fight hidden hunger in sub-Saharan Africa. Global Food Security 12:8-14.

Frelat, R., Lopez-Ridaura, S., Giller, K.E., Herrero, M., Douxchamps, S., Djurfeldt, A.A., Erenstein, O., Henderson, B., Kassie, M., Paul, B.K. and Rigolot, C. 2016. Drivers of household food availability in subSaharan Africa based on big data from small farms. Proceedings of the National Academy of Sciences 113:458-463.

Galili, G. and Amir, R. 2013. Fortifying plants with the essential amino acids lysine and methionine to improve nutritional quality. Plant Biotechnology Journal 11(2):211-222.

Graham, G.G., Lembcke, J. and Morales, E. 1990. Quality-protein maize as the sole source of dietary protein and fat for rapidly growing young children. Pediatrics 85:8591.

Gregory, T. and Sewando, P. 2013. Determinants of the probability of adopting quality protein maize (QPM) technology in Tanzania: A logistic regression analysis. International Journal of Development and Sustainability 2(2):729-746.

Ghimire, R. and Huang, W.C. 2015. Household wealth and adoption of improved maize varieties in Nepal: a double-hurdle approach. Food Security 7(6):1321-1335.

Ghosh, S., Suri, D. and Uauy, R. 2012. Assessment of protein adequacy in developing countries: quality matters. British Journal of Nutrition 108(S2):S77S87.

Goudet, S.M., Kimani-Murage, E.W., Wekesah, F., Wanjohi, M., Griffiths, P.L., Bogin, B. and Madise, N.J. 2017. How does poverty affect children's nutritional status in Nairobi slums? A qualitative study of the root causes of undernutrition. Public Health Nutrition 20(4):608-619.

Gunaratna, N.S., De Groote, H., Nestel, P., Pixley, K.V. and Mccabe, G.P. 2010. A meta-analysis of community-based studies on quality protein maize. Food Policy 35:202-210.

Gupta, H.S., Agrawal, P.K., Mahajan, V., Bisht, G.S., Kumar, A., Verma, P., Srivastava, A., Saha, S., Babu, R., Pant, M.C. and Mani, V.P. 2009. Quality protein maize for nutritional security: rapid development of short duration hybrids through molecular marker assisted breeding. Current Science 96(2):230-237.

Henley, E., Taylor, J. and Obukosia, S. 2010. The importance of dietary protein in human health: Combating protein deficiency in sub-Saharan Africa through transgenic 
biofortified sorghum. Advances in Food and Nutrition Research 60:21-52.

Hofer, M., Pozzi, A., Joray, M., Ott, R., Hähni, F., Leuenberger, M., von Känel, R. and Stanga, Z. 2014. Safe refeeding management of anorexia nervosa inpatients: An evidence-based protocol. Nutrition 30(5):524-530.

Hoseini, B. L., Emami Moghadam, Z., Saeidi, M., Rezaei Askarieh, M. and Khademi, G. 2015. Child Malnutrition at Different World Regions in 1990-2013. International Journal of Pediatrics 3:921-932.

Hulshof, T.G., van der Poel, A.F.B., Hendriks, W.H. and Bikker, P. 2017. Amino acid utilization and body composition of growing pigs fed processed soybean meal or rapeseed meal with or without amino acid supplementation. Animal 11(7):11251135.

Ignjatoviæ-Miciæ, D., Stankoviæ, G., Markoviæ, K., Laziæ-Janèiæ, V. and Deniæ, M. 2008. Quality protein maize: QPM. Genetika 40:205-214.

Ingale, S. and Shrivastava, S. 2011. Nutritional study of new variety of groundnut (Arachis hypogaea L.) JL-24 seeds. African Journal of Food Science 5:490-498.

Jensen, G.L., Bistrian, B., Roubenoff, R. and Heimburger, D. C. 2009. Malnutrition syndromes: a conundrum vs continuum. Journal of Parenteral and Enteral Nutrition 33:710-716.

Joint, F. 2012. WHO food standards programme codex committee on contaminants in foods. Fifth Session [displayed 10 February 2014]. Available at ftp://ftp. fao. org/codex/meetings/CCCF/ cccf5/cf05_INF. pdf, 2012. Accessed 17 July 2016.

Kadafur, M.I., Idrisa, Y.L., Kamara, A.Y. and Oyinbo, O. 2017. Understanding the Drivers of Adoption Intensity of Improved Maize Varieties in Northern Guinea Savannah of Borno State, Nigeria. Albanian Journal of Agricultural Sciences 16(2).
Kakooza Mwesige, A., Tumwine, J.K., Eliasson, A.C., Namusoke, H.K. and Forssberg, H. 2015. Malnutrition is common in Ugandan children with cerebral palsy, particularly those over the age of five and those who had neonatal complications. Acta Paediatrica 104(12):1259-1268.

Kinabo, J. 2014. The Policy Environment for Linking Agriculture and Nutrition in Tanzania-. J Kinabo-2014-agridiet. ucc. ie. Accessed on 15 August 2017

Kiria, C. G., Vermeulen, H. and De Groote, H. 2010. Sensory Evaluation and Consumers' Willingness to pay for quality protein maize (QPM) using experimental auctions in rural Tanzania. 3rd International Conference of the African Association of Agricultural Economists, Cape Town, South Africa 1923pp.

Krivanek, A. F., De Groote, H., Gunaratna, N. S. and Friesen, D. 2007. Breeding and disseminating quality protein maize (QPM) for Africa. African Journal of Biotechnology 6:312-324.

Kwiri, C. W., Muredzi, P., Tongonya, J., Gwala, W., Mujuru, F. and Sha, R. 2015. Mopane Worm (Gonimbrasia belina) Utilisation, a Potential Source of Protein in Fortified Blended Foods in Zimbabwe: A Review. Global Journal of Science Frontier Research 14:55- 66.

Langsten, R. 2014. Measuring Progress toward Universal Primary Education: An Examination of Indicators. Comparative Education Review 58(4):653-677.

Low, J., Ball, A., van Jaarsveld, P.J., Namutebi, A., Faber, M. and Grant, F.K. 2015. Assessing nutritional value and changing behaviours regarding orange-fleshed sweetpotato use in sub-Saharan Africa. Potato and sweetpotato in Africa: Transforming the value chains for food and nutrition security. CAB International. pp. 551-579.

López Barrios, L., Gutiérrez Uribe, J.A. and Serna Saldívar, S.O. 2014. Bioactive 
peptides and hydrolysates from pulses and their potential use as functional ingredients. Journal of Food Science 79:R273-R283.

Luong, T.T., Ninh, N.T. and Thanh, N.D. 2017. Cloning a lysine-rich protein gene from potato (Solanum tuberosum L.) cultivar Thuong Tin and construction of the expression vector. Tap Chi Sinh Hoc 38(4):497-504.

Mabhaudhi, T., Chibarabada, T. and Modi, A. 2016. Water-food-nutrition-health nexus: Linking water to improving food, nutrition and health in Sub-Saharan Africa. International Journal of Environmental Research and Public Health 13:107.

Machida, L., Derera, J., Tongoona, P., Langyintuo, A. and Macrobert, J. 2014. Exploration of Farmers' Preferences and Perceptions of Maize Varieties: Implications on Development and Adoption of Quality Protein Maize (QPM) Varieties in Zimbabwe. Journal of Sustainable Development 7:194-207.

Marra, M.V. and Boyar, A.P. 2009. Position of the American Dietetic Association: nutrient supplementation. Journal of the American Dietetic Association 109:2073-2085.

Marx, S., Phalkey, R., Aranda-Jan, C.B., Profe, J., Sauerborn, R. and Höfle, B. 2014. Geographic information analysis and webbased geoportals to explore malnutrition in Sub-Saharan Africa: a systematic review of approaches. BMC Public Health 14(1):1189.

Maseta, E., Mosha, T.C., Mosha, T.C., Nyaruhucha, C., Nyaruhucha, C., Laswai, H. and Laswai, H. 2017. Nutritional quality of quality protein maize-based supplementary foods. Nutrition \& Food Science 47(1):42-52.

May, J.F. 2017. The Politics of Family Planning Policies and Programs in sub Saharan Africa. Population and Development Review 43(S1):308-329.

Mbow, C., Van Noordwijk, M., Luedeling, E., Neufeldt, H., Minang, P.A. and Kowero, G. 2014. Agroforestry solutions to address food security and climate change challenges in Africa. Current Opinion in Environmental Sustainability 6:61-67.

Mbuya, K., Nkongolo, K., Kalonji-Mbuyi, A. and Kizungu, R. 2010. Participatory selection and characterization of quality protein maize (QPM) varieties in Savanna agroecological region of DR-Congo. Journal of Plant Breeding and Crop Science 2:325-332.

Mehrotra, S. 2006. Child malnutrition and gender discrimination in South Asia. Economic and Political Weekly:912-918.

Messing, J. and Wu, Y., Rutgers. 2017. Compositions and methods for rapid and efficient production of quality protein maize. U.S. Patent 9,603,317.

Mkonda, M.Y. and He, X. 2017. Tanzanian Controversy on Resources Endowments and Poverty. Environment and Ecology Research 5(1):30-38.

Motuma, N., Legesse, H. and Wolde, L. 2015. Evaluation of quality protein maize hybrids for yield, association of yield with its components and other agronomic traits at Bako, Ethiopia. Science, Technology and Arts Research Journal 4(3):18-25.

Morley E. J. 2016. Protein-Energy Undernutrition (PEU). http:// www.merckmanuals.com/professional/ nutritionaldisorders/undernutrition/proteinenergy-undernutrition-peu. Accessed on 10 October 2017.

Mpofu, A., Linnemann, A. R., Nout, M., Zwietering, M. H. and Smid, E. J. 2014. Mutandabota, a Food Product from Zimbabwe: Processing, Composition, and Socioeconomic Aspects. Ecology of Food and Nutrition 53:24-41.

Müller, O. and Krawinkel, M. 2005. Malnutrition and health in developing countries. Canadian Medical Association Journal 173:279-286.

Mubanga, K.H. and Ferguson, W. 2017. Threats to food sufficiency among smallholder farmers in Choma, Zambia. Food Security 9(4):745-758. 
Naidoo, K., Gichuhi, S., Basáñez, M.G., Flaxman, S.R., Jonas, J.B., Keeffe, J., Leasher, J.L., Pesudovs, K., Price, H., Smith, J.L. and Turner, H.C. 2014. Prevalence and causes of vision loss in subSaharan Africa: 1990-2010. British Journal of Ophthalmology 98(5):612-618.

Nhemachena, C., Mano, R., Mudombi, S. and Muwanigwa, V. 2014. Climate change adaptation for rural communities dependent on agriculture and tourism in marginal farming areas of the Hwange District, Zimbabwe. African Journal of Agricultural Research 9(26):2045-2054.

Notenbaert, A., Pfeifer, C., Silvestri, S. and Herrero, M. 2017. Targeting, out-scaling and prioritising climate-smart interventions in agricultural systems: Lessons from applying a generic framework to the livestock sector in sub-Saharan Africa. Agricultural Systems 151:153-162.

Nuss, E.T. and Tanumihardjo, S.A. 2010. Maize: A paramount staple crop in the context of global nutrition. Comprehensive Reviews in Food Science and Food Safety 9:417-436.

Nuss, E.T. and Tanumihardjo, S.A. 2011. Quality protein maize for Africa: closing the protein inadequacy gap in vulnerable populations. An International Review Journal 2:217-224.

Otemuyiwa, I.O. and Adewusi, S.R. 2014. Nutrient composition of some foods from a Nigerian eatery. Journal of Food Chemistry and Nutrition 2(1):11-18.

Orodho, J.A. 2014. Policies on free primary and secondary education in East Africa: Are Kenya and Tanzania on course to attain Education for All (EFA) Goals by 2015. International Organization of Scientific Research (IOSR) Journal of Humanities and Social Sciences (IOSR-JHSS) 19:1120.

Owach, C., Bahiigwa, G. and Elepu, G. 2017. Factors Influencing the Use of Food Storage Structures by Agrarian Communities in Northern Uganda. Journal of Agriculture, Food Systems, and Community Development 7(2):127-144.

Owuamanam, C., Ogueke, C., Iwouno, J. and Edom, T. 2014. Use of Seed Sprouting in Modification of Food Nutrients and Pasting Profile of Tropical Legume Flours. Nigerian Food Journal 32:117-125.

Pandey, N., Hossain, F., Kumar, K., Vishwakarma, A.K., Muthusamy, V., Saha, S., Agrawal, P.K., Guleria, S.K., Reddy, S.S., Thirunavukkarasu, N. and Gupta, H.S. 2016. Molecular characterization of endosperm and amino acids modifications among quality protein maize inbreds. Plant Breeding 135(1):47-54.

Phalkey, R.K., Aranda-Jan, C., Marx, S., Höfle, B. and Sauerborn, R. 2015. Systematic review of current efforts to quantify the impacts of climate change on undernutrition. Proceedings of the National Academy of Sciences 112(33):E4522E4529.

Potrykus, I. 2017. The GMO-crop potential for more, and more nutritious food is blocked by unjustified regulation. Journal of Innovation \& Knowledge 2(2):90-96.

Prasanna, B., Vasal, S., Kassahun, B. and Singh, N. 2001. Quality protein maize. Current Science 81:1308.

Puskur, R., Park, S., Bourgeois, R., Hollows, E., Suri, S. and Phillips, M. 2017. 10 Exploring futures of aquatic agricultural systems in Southern Africa. Sustainable Intensification in Smallholder Agriculture: An Integrated Systems Research Approach143.

Rajendran, A., Muthiah, A., Joel, J., Shanmugasundaram, P. and Raju, D. 2014. Heterotic grouping and patterning of quality protein maize inbreds based on genetic and molecular marker studies. Turkish Journal of Biology 38:10-20.

Setimela, P.S., Magorokosho, C., Lunduka, R., Gasura, E., Makumbi, D., Tarekegne, A., Cairns, J.E., Ndhlela, T., Erenstein, O. and Mwangi, W. 2017. On-Farm Yield Gains with Stress-Tolerant Maize in Eastern and 
Southern Africa. Agronomy Journal 109(2):406-417.

Sharma, P., Aggarwal, P. and Kaur, A. 2017. Biofortification: a new approach to eradicate hidden hunger. Food Reviews International 33(1):1-21.

Shiferaw, B., Tesfaye, K., Kassie, M., Abate, T., Prasanna, B.M. and Menkir, A. 2014. Managing vulnerability to drought and enhancing livelihood resilience in subSaharan Africa: Technological, institutional and policy options. Weather and Climate Extremes 3:67-79.

Singh, P.K., Singh, A.K., Shahi, J.P. and Ranjan, R. 2012. Combining ability and heterosis in quality protein maize. The Bioscan 7(2):37-340.

Sivaramakrishnan, M. and Patel, V.L. 2017. Models of health beliefs in South India: impact on managing childhood nutritional illnesses. In Cognitive Informatics in Health and Biomedicine Springer International Publishing. pp. 89-116.

Sofi, P., Wani, S. A., Rather, A. and Wani, S. H. 2009. Review article: Quality protein maize (QPM): Genetic manipulation for the nutritional fortification of maize. Journal of Plant Breeding and Crop Science 1:44253.

Steyn, N. P. and Mchiza, Z. J. 2014. Obesity and the nutrition transition in Sub Saharan Africa. Annals of the New York Academy of Sciences 1311:88-101.

Sunguya, B.F., Ong, K.I., Dhakal, S., Mlunde, L.B., Shibanuma, A., Yasuoka, J. and Jimba, M. 2014. Strong nutrition governance is a key to addressing nutrition transition in low and middle-income countries: review of countries' nutrition policies. Nutrition Journal 13:65.

Talsma, E.F., Brouwer, I.D., Verhoef, H., Mbera, G.N., Mwangi, A.M., Demir, A.Y., Maziya-Dixon, B., Boy, E., Zimmermann, M.B. and Melse-Boonstra, A. 2016. Biofortified yellow cassava and vitamin A status of Kenyan children: A randomized controlled trial. The American Journal of Clinical Nutrition 103:258-267.

Thierfelder, C., Chivenge, P., Mupangwa, W., Rosenstock, T.S., Lamanna, C. and Eyre, J.X. 2017. How climate-smart is conservation agriculture (CA)? - its potential to deliver on adaptation, mitigation and productivity on smallholder farms in southern Africa. Food Security:1-24.

Taipale, S. 2013. The use of e-government services and the Internet: The role of sociodemographic, economic and geographical predictors. Telecommunications Policy 37(4):413-422.

Twumasi-Afriye, S., Palacios Rojas, N., Friesen, D., Teklewold, A., Gissa, D.W., De Groote, H. and Prasanna, B.M. 2016. Guidelines for the quality control of Quality Protein Maize (QPM) seed and grain: Technical bulletin. 38 p. Addis Ababa, Ethiopia. CGIAR. CIMMYT 38pp.

Ubesie, A. and Ibeziakor, N. 2013. High Burden of Protein-Energy Malnutrition in Nigeria: Beyond the Health Care Setting. Annals of Medical and Health Sciences Research 2:66-69.

United Nations Childen's Fund. 2013. The right ingredients: The need to invest in child nutrition. London: United Nations Children's Fund (UNICEF), UK.

van der Pols-Vijlbrief, R., Wijnhoven, H. A., Schaap, L. A., Terwee, C. B. and Visser, M. 2014. Determinants of protein-energy malnutrition in community-dwelling older adults: A systematic review of observational studies. Ageing Research Reviews 18:112131.

Vaswani, S., Kumar, R., Kumar, V., Roy, D. and Kumar, M. 2015. In Vitro Nutritional Evaluation of Normal and Quality Protein Maize Fodders for Ruminants. Indian Journal of Animal Nutrition 32(1):20-24.

Wahab, M., Mahmood, J. and Oluleye, F. 2012. Yield and disease reactions of quality protein maize varieties in the southern Guinea savanna agro-ecology of Nigeria. 
International Journal of Agriculture and World Health Organization. 2014. WHO Forestry 2:203-209. biennial report: Rwanda country office Wirth, J.P., Petry, N., Tanumihardjo, S.A., 2012-2013. Accessed 4 November 2017. Rogers, L.M., McLean, E., Greig, A., Zinkina, J. and Korotayev, A. 2014. Explosive Garrett, G.S., Klemm, R.D. and Rohner, population growth in tropical Africa: F. 2017. Vitamin A supplementation Crucial omission in development forecasts programs and country-level evidence of vitamin A deficiency. Nutrients 9:190. - emerging risks and way out. World Futures 70(2):120-139. 